\title{
Kualitas Sistem Pembelajaran Pengajar Tahsin dan Tahfizh di Organisasi Startup Pengajar Diponegoro Yogyakarta
}

\author{
Sigit Yuli Pramono 4 \\ kaksigit@gmail.com
}

\begin{abstract}
This type of research was field research, which used qualitative description in order to know the quality of the instructors of tahsin and tahfiz learning system in the Pengajar Diponegoro startup organization Yogyakarta. Method used is qualitative method with interview technique and documentation. interview data collection technique was obtained through data triangulation, namely: official responses, teacher and client about quality of the instructors learning system of tahsin and tahfiz in the Pengajar Diponegoro startup. The results showed that the Pengajar Diponegoro startup organization Yogyakarta has concern about quality of the instructor learning system of tahsin and tahfiz. This has proven some result including: (1) official has prepared e-learning website including learning implementation plan and learning resource, (2) implementation of quality of learning system had made better through the official development team learning, through the planning process, (3) evaluation of quality of learning system must be done to improve the quality of the learning process adjusted to the objectives of planning and implementation, (4) the quality standard of learning system has already fulfilled the better result, (5) from the characteristic of view, the total quality management has already fulfilled the characteristics.
\end{abstract}

Keywords: System Quality, Teacher Learning, Startup Learning, Quality Standards

${ }^{4}$ Teknologi Pembelajaran, Universitas Negeri Yogyakarta 


\section{PENDAHULUAN}

$\mathrm{H}$ akikat pendidikan adalah mengembalikan nilai-nilai ilahia pada manusia (fitrah) dengan bimbingan Alquran dan Sunah, sehingga menjadi manusia yang berakhlak mulia (Salahudin, 2017). Rasullulah Muhammad Saw telah memberikan contoh pembelajaran dari segi perkataan, perbuatan, maupun ketetapannya sebagai rasul. Perilaku Rasullulah Saw sebagai contoh semua umatnya yang beragama islam, karena didalam perilaku, perbuatan, perkataan, sikap, maupun kebiasaan terdapat suri tauladan yang baik. Suri tauladan yang baik sebagaimana dijelaskan dalam firman Allah SWT, yang menyatakan dalam QS. Al Ahzab, 21 "Laqad kāna lakum fĩ rasụlillāhi uswatun ḥasanatul limang kāna yarjullāha wal-yaumal-ākhira wa żakarallāha kaṡīrā yang artinya esungguhnya telah ada pada (diri) Rasulullah itu suri teladan yang baik bagimu (yaitu) bagi orang yang mengharap (rahmat) Allah dan (kedatangan) hari kiamat dan dia banyak menyebut Allah (Depag, 1993)

Rasulullah SAW sebagai penyampai kitab suci Alquran kepada umatnya dan Alquran juga sebagai risalah ke-Nabian. Proses pengamalan Alquran, awal mula disampaikan kepada lima sahabat Rasulullah Saw yakni: (1) Zaid bin Tsabit Ra., (2) Ubay bin Ka'ab Ra., (3) 'Ali bin Abi Tholib Ra., (4) 'Utsman bin Affan Ra., (5) 'Abdullah bin Mas'ud Ra. Kelima sahabat Rasulullah Saw tersebut yang menerima pembelajaran Alquran dari Rasulullah. Sampainya Alquran ke Asian tenggara melalui Abdullah bin Mas'ud disampaikan kepada Abdurrahman 'Abdullah bin Hubaib As Sulamiy, lanjut disampaikan kepada 'Ashim bin Abu An Najud Al Asadiy Al Kufi (wafat $128 \mathrm{H}$ ), berlanjut disampaikan Hafs bin Sulaiman bin Mughrah Al Bazz Al Kufi (wafat $180 \mathrm{H}$ ), dari riwayat Hafs ini bacaan Alquran Rasulullah sampai ke Indonesia oleh para ulama yang belajar Alquran kepada Hafs (Imana, 2016).

Tahsin dan Tahfizh yakni suatu pembelajaran yang tidak lepas, ketika akan mempelajari Alquran. Tahsin berasal dari kata "attahsin u wattajmillu wattazyiinu wal iiqaanu" artinya membaguskan, memperindah, menghias, mengkonsistenkan, jadi dari kata tersebut Tahsin adalah membaguskan, memperindah, menghias, mengkonsistenkan bacaan Alquran (Imana, 2016). Ilmu untuk mempelajari Tahsin adalah ilmu Tajwid. Tajwid menurut istilah ialah "ikhraaju kullu harfin min makhrajihi ma'a l'thaaihihaqqahu wa mustahaqqahu" yang artinya mengeluarkan sifat huruf dari makhrajnya dengan memberikan haq dan mustahaqnya (Rauf, 2004). Tahfizh yang berarti menghafal, menghafal dari kata dasar hafal dari bahasa Arab hafizha - yahfazhu - hifzhan, lawan dari lupa, yaitu selalu ingat dan sedikit lupa (Yunus, 1989). Kedua ilmu tersebut sangat diperlukan oleh calon peserta untuk belajar Alquran, domain membaca yakni tahsin dan domain menghafal yakni tahfizh.

Tujuan pembelajaran yakni mencerdaskan kehidupan bangsa, sesuai falsafah undang-undang dasar 1945 (UUD, 1945), dan tugas guru adalah pendidik profesional dengan tugas utama mendidik, mengajar, membimbing, mengarahkan, melatih, menilai, dan mengevaluasi peserta didik (PLPG, 2016). Kualitas sistem pembelajaran pengajar di organisasi startup Pengajar Diponegoro merupakan faktor penting dalam membentuk pengajar menjadi pengajar yang penuh dengan sikap optimisme, keberanian dan keterampilan. Kualitas sistem pembelajaran dapat dilihat pada beberapa variabel seperti mendidik, mengajar, membimbing, mengarahkan, melatih, menilai, dan mengevaluasi. Organisasi startup Pengajar Diponegoro Yogyakarta memiliki kepedulian terhadap kualitas sistem pembelajaran dan hal ini telah dibuktikan dengan beberapa penghargaan yang diterima oleh Organisasi startup Pengajar Diponegoro ini. 
Pada tanggal 14 Juli 2018, Organisasi Startup Pengajar Diponegoro dianugerahi juara dua dalam kompetisi usaha bidang startup di Poltekes Kemenkes Yogyakarta. Pada tanggal 14 November 2018, Organisasi startup Pengajar Diponegoro dianugerahi semi finalis dalam kompetisi kewirausaha bidang startup di Universitas Gajah Mada, Yogyakarta. Pada tanggal 18 Desember 2018, organisasi startup Pengajar Diponegoro berhasil mendapat juara dua dalam kompetisi kewirausaha bidang startup Pelayanan Pengajar Tahsin dan Tahfizh di Universitas Teknologi Yogyakarta.

Sistem kerja Startup Pengajar Diponegoro ialah dengan cara membuat e-learning, berupa website dengan nama domain www.pengajardiponegoro.org. Website tersebut mempunyai menu berbasis Moodle. Moodle adalah website e-learning untuk kursus online yang bersifat open source (tanpa berbayar). Website tersebut oleh Organisasi Startup Pengajar Diponegoro dimanfaatkan sebagai optimalisasi kemampuan pengajar Tahsin dan Tahfizh.

Berdasarkan latar belakang penelitian, penulis tertarik untuk melakukan penelitian terkait kualitas sistem pembelajaran pengajar tahsin dan tahfizh di organisasi startup Pengajar Diponegoro, Yogyakarta.

\section{METODE PENELITIAN}

Penelitian ini dilaksanakan di organisasi startup Pengajar Diponegoro Yogyakarta. Data yang diperoleh adalah data observasi, wawancara, dokumentasi dan analisis data. Teknik pengumpulan data wawancara diperoleh melalui triangulasi data, dari hasil wawancara tiga komponen yang berbeda yakni: tanggapan Official, Pengajar dan Client tentang kualitas sistem pembelajaran pengajar Tahsin dan Tahfizh di Organisasi Startup Pengajar Diponegoro.

Pendekatan yang diterapkan adalah pendekatan fenomenologis dari penelitian naturalistik, pendekatan ini bertujuan untuk mengetahui original pelaksanaan kegiatan di Organisasi Startup Pengajar Diponegoro. Posedur penelitian menggunakan wawancara semi terstruktur meliputi topik: (1) perencanaan mutu kualitas pembelajaran, (2) implementasi kualitas sistem pembelajaran di Organisasi Startup Pengajar Diponegoro, dan (3) evaluasi kualitas sistem pembelajaran di Organisasi Startup Pengajar Diponegoro.

Untuk mengetahui standar kualitas sistem pembelajaran di Organisasi Startup Pengajar Diponegoro, peneliti menggunakan pedoman sistem penjaminan mutu internal pendidikan akademik, pendidikan vokasi, pendidikan profesi dari Direktorat Penjaminan Mutu tahun 2018. Standar mutu pembelajaran tersebut dilihat dari 4 komponen, yakni: (1) proses atau kegiatan, (2) prosedur atau mekanisme, (3) hasil atau output, dan (4) dampak atau outcomes, yang dilaksanakan oleh Organisasi Startup Pengajar Diponegoro, Yogyakarta.

Untuk mengetahui karakteristik manajemen di Organisasi Startup Pengajar Diponegoro, peneliti menggunakan pedoman sepuluh karakteristik Total Quality Management (TQM) dari Rochaety, yaitu: (1) fokus pada pelanggan (internal \& eksternal), (2) berorientasi pada kualitas, (3) menggunakan pendekatan ilmiah, (4). memiliki komitmen jangka panjang, (5) kerja sama tim, (6) menyempurnakan kualitas secara berkesinambungan, (7) mengadakan pendidikan dan pelatihan, (8) menerapkan kebebasan yang terkendali, (9) memiliki kesatuan tujuan, (10) melibatkan dan memberdayakan karyawan. 


\section{HASIL DAN PEMBAHASAN}

\section{Kerangka Teoritis}

1. Pembelajaran

Kata "pembelajaran" didefinisikan suatu usaha untuk membuat peserta didik belajar atau suatu kegiatan untuk membelajarkan perserta (Warsito, 2008). Beberapa tokoh pendidikan mendiskripsikan tetang pembelajaran diantaranya; (1) Pembelajaran adalah kegiatan pendidik secara terprogram dalam mendesain instruksional untuk membuat peserta didik belajar dengan aktif yang menekankan pada penyediaan sumber belajar (Dimyati, \& Mudjiono, 2002), (2) pembelajaran adalah suatu kombinasi yang tersusun meliputi unsur-unsur manusiawi, material fasilitas, perlengkapan dan prosedur yang saling mempengaruhi mencapai tujuan pembelajaran, dan prosedur yang meliputi: jadwal, metode penyampaian informasi, praktek, belajar dan ujian (Hamalik, 2006). Media modul memfasilitasi kegiatan belajar siswa seperti definisi berikut ini "media enriches the learning activities of students and facilitates group discussions, and hence, their use should be encouraged in learning and teaching processes in higher education institutions" (Al-Rahmi, et al. 2018). Dalam kegiatan pembelajaran guru dituntut untuk mampu memilih media pembelajaran yang tepat, dan sesuai dengan tujuan yang akan dicapai (Tiari, Suryani, \& Suharno, 2016).

\section{Tujuan Pembelajaran}

Tujuan pembelajaran yakni "to provide educators and trainers with prescriptions for making their instruction more effective and appealing" (Reigeluth, 1997). Dalam proses pembelajaran ada interaksi mengajar yang dilakukan oleh seorang guru. Subroto mengartikan mengajar adalah suatu aktivitas mengorganisasi atau mengatur lingkungan sebaik-baiknya dan menghubungkannya dengan anak sehingga terjadi belajar mengajar (Subroto, 1997). Dalam pembelajaran e-learning, semua peserta didik harus mampu belajar mandiri. Peserta didik yang diajarkan menggunakan media pembelajaran dengan kemandirian belajar hasilnya lebih baik dibandingkan peserta didik yang diajarkan secara konvensional (Lestari, Sunardi \& Suryani, 2017). E-Learning yang mampu meningkatkan hasil belajar dan prestasi peserta didik (Pirmansah, Suharno \& Fadhilah, 2017). Media yang dipakai dalam e-learning seperti: Modul, jobsheet dan handout. Tujuan dari modul menjadikan bahan ajar pegangan mandiri sesuai definisi sebagai berikut: "There were challenges in the development, implementation, and evaluation of this project. There was a substantial amount of information on experiential education and teaching in the experiential setting that could have been conveyed in each of the modules" (Dhaliwal, Simpson, \& KimSing, 2018). Modul pembelajaran mandiri (self Instruction) adalah alat yang berguna untuk mememperdalam pendidikan, sesuai definisi: "Self-instructional modules are a useful tool for furthering education" (Banerjee, 2019).

\section{Mutu Pengajar}

Standar mutu pembelajaran dilihat dari 4 komponen: (1) proses atau kegiatan, (2) prosedur atau mekanisme, (3) hasil atau output, dan (4) dampak atau outcomes (Direktorat Penjaminan Mutu, 2018). Proses pembelajaran atau kegiatan yang telah selesai dilakukan, yang disebut juga sebagai summative evaluation. Evaluasi seperti ini bersifat komprehensif dan utuh, sehingga bukan hanya hasil (output) yang dinilai melainkan juga dampak atau (outcomes) dari sebuah proses atau kegiatan. Monitoring adalah suatu penilaian juga, tetapi dilakukan ketika kegiatan yang dinilai itu masih berjalan, atau disebut sebagai formative evaluation (Direktorat Penjaminan Mutu, 2018). 
Kementerian Riset, Teknologi, dan Pendidikan Tinggi mencatat sekitar 8,8\% dari total 7 juta pengangguran di Indonesia adalah sarjana. Kondisi tersebut sangat mengkhawatirkan mengingat persaingan untuk mendapatkan pekerjaan akan semakin ketat dengan datangnya Revolusi Industri 4.0. Selain bersaingan dengan mesin berbasis teknologi canggih, sekitar 630.000 sarjana pengangguran tersebut juga harus beradu kompetensi dan keahlian tertentu dengan pekerja asing yang datang dari terbukanya pasar bebas (Ira, 2017).

Perguruan tinggi sebagai lembaga pencetak sumber daya manusia yang unggul diharapkan dapat memberi kontribusi besar terhadap upaya peningkatan kapasitas sumber daya manusia (Seftiawan, 2018). Ghufron mencontohkan, salah satu program studi yang lulusannya sudah menjamur, namun kurang terserap di bidangnya adalah pendidikan guru. Berdasarkan data, lulusan guru yang menjalankan profesi guru hanya 15 sampai 20 persen. Sehingga, lanjut Ghufron, jangan sampai perguruan tinggi hanya mencetak sarjana yang ke depannya justru menjadi pengangguran (Ira, 2017).

Dari uraian ini dapat disimpulkan bahwa lulusan sarjana termasuk lulusan guru yang menjalankan profesi guru di Indonesia dibutuhkan lapangan pengajaran yang memadai.

\section{Progess Terhadap Kualitas Sistem Pembelajaran}

Proses pembelajaran mempunyai dua karakteristik: Pertama, dalam proses pembelajaran melibatkan proses berfikir. Kedua, dalam proses pembelajaran membangun suasana dialogis dan proses tanya jawab terus menerus yang diarahkan untuk memperbaiki dan meningkatkan kemampuan berfikir peserta didik, yang pada gilirannya kemampuan berfikir itu dapat membantu peserta didik untuk memperoleh pengetahuan yang mereka konstruksi sendiri (Sagala, 2004). Faktor-faktor peningkatan mutu pendidikan melalui inovasi-inovasi pembelajaran (Saifulloh, Muhibbin \& Hermanto, 2012) dan mengembangkan keterampilan belajar mandiri yang lebih kaya. Selain itu, guru berpotensi menggunakan alat diagnostik untuk menganalisis siswa mana yang membutuhkan dukungan sesuai definisi berikut: "ultimately to develop richer self-regulated learning skills. Also, teachers could potentially use a diagnostic tool to analyze which students are in need of support" (Molenaar, Horvers, \& Baker, 2019).

Kualitas sistem pembelajaran banyak yang mengadopsi dari teori Total Quality Management (TQM). Konsep teori TQM mudah dipraktekkan untuk manajemen pendidikan. Edward Sallis menyatakan bahwa Total Quality Management (TQM) pada pendidikan adalah sebuah filsosofis tentang perbaikan secara terus-menerus yang dapat memberikan seperangkat alat praktis kepada setiap institusi pendidikan dalam memenuhi kebutuhan, keinginan, dan harapan para pelanggannya saat ini dan untuk masa yang akan datang (Sallis, 2006).

Sepuluh karakteristik TQM yang dianggap penting untuk meningkatkan dunia pendidikan, yaitu: (1) fokus pada pelanggan (internal \& eksternal), (2) berorientasi pada kualitas, (3) menggunakan pendekatan ilmiah, (4). memiliki komitmen jangka panjang, (5) kerja sama tim, (6) menyempurnakan kualitas secara berkesinambungan, (7) mengadakan pendidikan dan pelatihan, (8) menerapkan kebebasan yang terkendali, (9) memiliki kesatuan tujuan, (10) melibatkan dan memberdayakan karyawan (Rochaety, Rahayuningsih \& Yanti, 2005).

Karakteristik proses pembelajaran diarahkan untuk melibatkan proses berfikir sekaligus memperbaiki dan meningkatkan kemampuan berfikir peserta didik. Karakteristik proses pembelajaran akan digunakan dalam penelitian pembelajaran di Organisasi Startup Pengajar Diponegoro Diponegoro, 
Yogyakarta. Sepuluh karakteristik TQM digunakan untuk mengetahui Kualitas Sistem Pembelajaran di Pengajar Diponegoro Yogyakarta.

\section{Hasil}

Untuk mewujudkan kualitas pembejaran Organisasi Startup Pengajar Diponegoro. Organisasi Startup tersebut memberikan jaminan mutu kepada peserta didik, yakni calon pengajar tahsin dan tahfizh. Calon pengajar tahsin dan tahfizh sebelum diberi tugas untuk mengajar di majelis atau tempat pembelajaran Al-quran, maka diberi sosialisasi tentang ikut serta dalam pelatihan online terlebih dahulu.

Melalui sosialisasi dan ikut serta dalam pelatihan online maka semua calon pengajar tahsin dan tahfizh memiliki persepsi dan arah tujuan yang sama dalam melaksanakan semua kegiatan. Pelatihan Online diselingi beberapa indikator prestasi seperti resume modul yang ada di dalam website e-learning moodle.

Indikator penilaian pengajar tahsin dan tahfizh dilihat pada aspek:

1. proses atau kegiatan pembelajaran tahsin dan tahfizh

2. prosedur atau mekanisme pembelajaran tahsin dan tahfizh

3. hasil atau output pembelajaran tahsin dan tahfizh

4. dampak atau outcomes pembelajaran tahsin dan tahfizh

Prestasi-prestasi Organisasi Pengajar Diponegoro seperti:

1. Juara 2 kompetisi kewirausaha bidang startup Pelayanan Pengajar Tahsin dan Tahfizh Tingkat Yogyakarta di Poltekes Kemenkes Yogyakarta.

2. Semi Finalis kompetisi kewirausaha bidang startup Penyediaan Pengajar Tahsin dan Tahfizh, Tingkat Nasional di Universitas Gajah Mada.

3. Juara 2 kompetisi kewirausaha bidang startup Penyelenggaraan Pengajar Tahsin dan Tahfizh tingkat Yogyakarta di Universitas Teknologi Yogyakarta.

Untuk mendukung semua program ini, Organisasi Startup Pengajar Diponegoro menanamkan kualitas sistem pembelajaran, seperti:

1. Calon pengajar tahsin dan tahfizh mengumpulkan berkas identitas lengkap ke admin.

2. Ketika pengajar calon pengajar tahsin dan tahfizh di wawancara, calon pengajarnya di tes bacaan Alqurannya terlebih dahulu. Wawancarapun bisa menggunakan Aplikasi Whatsapp, untuk bacaan Alquran bisa direkam.

3. Ketika tahap pengumpulan berkas identitas, wawancara dan tes bacaan Alquran selesai dilakukan, maka peserta melanjutkan pelatihan online dengan moodle e-learning.

4. Selesainya calon pengajar tahsin dan tahfizh belajar online dan me-review semua modul pengajaran, maka calon pengajar berubah statusnya menjadi pengajar tahsin dan tahfizh pengajar diponegoro.

5. Admin Pengajar Diponegoro memberikan apresiasi, untuk pengajar baru yang telah selesai menjalankan pelatihan online. Apresiasi tersebut dikirim melalui resmi Pengajar Diponegoro ke e-mail pengajar baru.

Pengajar baru yang lolos seleksi berhak mendapatkan jam mengajar, untuk jam pengajaran pengajar baru di kelas privat dan majelis binaan Organisasi Startup Pengajar Diponegoro. Domain 
pengajaran yang diajarkan hanya materi tahsin dan tahfizh, sehingga kualitas materi yang dipelajari lebih terarah.

\section{Temuan Khusus}

1. Perencanaan Mutu Kualitas Pembelajaran

Berdasarkan wawancara dengan official Pengajar Diponegoro, official mempresentasikan perencanaan program secara umum kualitas sistem pembelajaran di Organisasi Startup Pengajar Diponegoro. Perencanaan perbaikan Kualitas sistem pembelajaran adalah program umum dengan target mencakup semua karyawan, seperti official, pengajar dan client. Program tersebut untuk meningkatkan kualitas sistem pembelajaran, diantaranya:

a. Calon pengajar tahsin dan tahfizh mengumpulkan berkas identitas lengkap ke admin.

b. Ketika pengajar calon pengajar tahsin dan tahfizh di wawancara, calon pengajarnya di tes bacaan Alqurannya terlebih dahulu. Wawancarapun bisa menggunakan Aplikasi Whatsapp, untuk bacaan Alquran bisa direkam.

c. Ketika tahap pengumpulan berkas identitas, wawancara dan tes bacaan Alquran selesai dilakukan, maka peserta melanjutkan pelatihan online dengan website moodle e-learning.

d. Selesainya calon pengajar tahsin dan tahfizh belajar online dan me-review semua modul pengajaran, maka calon pengajar berubah statusnya menjadi pengajar tahsin dan tahfizh Pengajar Diponegoro.

Admin Pengajar Diponegoro memberikan apresiasi, untuk pengajar baru yang telah selesai menjalankan pelatihan online. Apresiasi tersebut dikirim melalui e-mail resmi Pengajar Diponegoro ke email pengajar baru.

Saat penulis mengajukan pertanyaan ke official Pengajar Diponegoro, tentang perencanaan mutu pengajaran tahsin dan tahfizh di Organisasi Startup Pengajar Diponegoro. Official Pengajar Diponegoro menjawab:

".....Dalam pengajaran tahsin dan tahfizh, kelas dibagi sesuai umur, Karena kita tidak bisa menyamakan pembelajaran murid yang sudah dewasa dengan anak, yang masih anak-anak diselipkan permainan dan cenderung tidak terlalu dipercepat. Sementara orang dewasa kadang mengalami jenuh jika proses pembelajaran dilakukan dengan panjang...." -Official A-

Pertanyaan lain kemudian diberikan kepada official Pengajar Diponegoro, bagaimana kualitas iklim belajar tahsin dan tahfidz di Organisasi Startup Pengajar Diponegoro.

"...Iklim yang ada sangat mendukung untuk perkembangan murid yang diajar, karena selain bisa berkonsultasi secara langsung untuk perkembangan dirinya. Para murid bisa melakukan konsultasi lewat sosial media atau online untuk mendapatkan saran agar pembelajaran dapat dilakukan dengan lebih efektif...." Oofficial A-

Penulis kemudian memberikan pertanyaan tentang kualitas sistem pembelajaran di Organisasi Startup Pengajar Diponegoro kepada pengajar 
"... dalam perencanaan kualitas sistem pembelajaran, pengajar mengikuti pelatihan online melalui website e-learning. Kualitas pembelajaran pengajar Diponegoro sangat baik, karena semua Official memberikan penjelasan yang sangat mudah dimengerti selama pembelajaran..." -Pengajar A-

Kemudian penulis mengajukan pertanyaan kepada Client yang kerjasama dalam pembinaan kelas Tahsin dan Tahfizh tentang kualitas pembelajaran yang diberikan oleh Pengajar Diponegoro. Dan client pengajar diponegoro menjawab sebagai berikut:

"...Perencanaan mutu pembelajaran tahsin dan tahfizh dalam waktu minimal 2 tahun anak diharap sudah bisa membaca Alquran secara tahsin dan tahfizh. Kualitas pembembelajaran baik anak merasa nyaman den senang dengan metode pembelajarannya..." -Client A-.

Berdasarkan data dan fakta sebagaimana disajikan pada bagian wawancara di atas, jawaban responden ditunjukkan bahwa perencanaan kualitas sistem pembelajaran di Organisasi Startup Pengajar Diponegoro adalah baik, misalnya rencana Official harus menyiapkan sebuah program website e-learning dan persiapan penyusunan rencana pengajaran sudah disiapkan materi-materi terlebih dahulu. Ini membuktikan bahwa upaya yang dilakukan bertujuan untuk meningkatkan kualitas sistem pembelajaran di Pengajar Diponegoro.

\section{Implementasi Kualitas Sistem Pembelajaran di Organisasi Startup Pengajar Diponegoro}

Berdasarkan wawancara dengan Official Pengajar Diponegoro, penulis mengekspos hal tentang pelaksanaan kualitas sistem pembelajaran pengajar tahsin dan tahfizh di Organisasi Startup Pengajar Diponegoro

“...bagi official, dalam penerapannya pembelajaran sudah baik, karena selain pengajar yang ada sudah mumpuni dalam bidangnya. Rata-rata para pengajarnya juga sudah berpengalaman dan untuk pengajar baru diberikan bimbingan lewat website untuk mengembangan kemampuannya...." -Official B-

"...bagi pengajar tahsin, proses pembelajaran Tahsin dilakukan dengan memberikan contoh terhadap murid dan penjelasannya. Selanjutnya dibaca secara bersama dan perorangan, untuk selanjutnya dilakukan koreksi oleh pengajar..."-Pengajar B-

"...bagi pengajar tahfizh, untuk Tahfizh dilakukan dengan cara pengajar memberikan contoh terlebih dahulu, kemudian murid mengikuti bacaan pengajarnya. Hal ini dilakukan untuk murid yang masih belum lancar. Murid yang belajar Tahfizh masih sering ditemui kesalahan dalam melakukan hafalan, sehingga pengajar meberikan contoh supaya hafalan yang sudah dihafal tidak salah..." Pengajar A-

Kemudian wawancara dengan personil pengajar yang bertugas di binaan privat, atau majelis, penulis mengekspos hal tentang pelaksanaan Kualitas Sistem Pembelajaran pengajar tahsin dan tahfizh di Organisasi Startup Pengajar Diponegoro, dan jawaban yang diberikan sebagai berikut:

"....penerapan pembelajaran tahsin dan tahfizh di kelas binaan privat atau majelis sejauh ini sudah bagus karena sudah dilatih dan dididik sebelum mengajar, mungkin sistem pembelajaran lebih dievaluasi lagi supaya ketika ngajar santai..." -Pengajar C-

"...ketika pengajar mengajar di binaan, pengajar menjelaskan dan memberi contoh dan murid mengikutinya kemudia murid di test satu persatu..."-Pengajar C- 
Kemudian sebuah pertanyaan diberikan kepada client yang berkerjasama untuk pelayan pengajaran tahsin dan tahfizh di kelas binaan, dan jawaban yang diberikan:

“...bagi client yang kerjasama dengan Pengajar Diponegoro, implementasi pembelajaran tahsin dan tahfizh, untuk siswa nyaman dengan metode yang digunakan oleh pengajar dalam hal penyampaian..." -Client B-

"...proses pembelajaran tahsin dan tahfizh, dilakukan secara bertahap, berulang-ulang, dan rutin..." -Pengajar C-

Dari data di atas, terlihat bahwa Organisasi Startup Pengajar Diponegoro memiliki kepedulian besar dalam memperbaiki kualitas sistem pembelajaran di seluruh kegiatan proses pembelajaran telah dilakukan diatur dalam perencanaan, sehingga semua ini menjadi wajib dilakukan dengan baik oleh para official, para pengajar, dan client menggunakan pelayanan pengajar tahsin dan tahfizh. Semuanya telah terjadi dibuat dengan baik oleh Organisasi Startup Pengajar Diponegoro dan tim official dari pengembangan sekolah melalui proses perencanaan.

\section{Evaluasi Kualitas Sistem Pembelajaran di Organisasi Startup Pengajar Diponegoro}

Jika calon pengajar baru tidak memenuhi target yang telah ditetapkan, maka calon pengajar baru harus melakukan beberapa hal seperti yang telah ditentukan. Menurut hasil wawancara yang dilakukan oleh penulis dengan kepada official, Ada beberapa hal yang harus dilakukan oleh para calon pengajar baru:

“...Evaluasi dilakukan secara langsung lewat pengajar yang bersangkutan maupun menggunakan kertas penilaian untuk melihat perkembangan dari calon pengajar baru yang dilatih dari waktu ke waktu..." -Official A-

“...Tes calon pengajar baru dilakukan pada waktu yang telah ditentukan dengan cara melakukan tes bacaan maupun hafalan lewat sosial media atau tatap muka..." -Official A-

Lalu wawancara official Organisasi Startup Pengajar Diponegoro, tentang prosedur, output dan outcomes, dinyatakan sebagai berikut:

“...Pembelajaran dimulai dengan salam, penyampaian hadist yang dapat memberikan motivasi kepada murid, membaca doa bersama-sama. Kemudian dilanjutkan dengan pembelajaran yang dilakukan dalam 1x60 menit beserta doa dan lain-lain. Selanjutnya ditutup dengan hamdallah dan doa penutup..." -Official A-

"...Calon pengajar baru dapat membaca dengan lancar sesuai kaidah ilmu tajwid untuk tahsin dan memiliki hafalan untuk kelas tahfizh..." -Official A-

"...Pembelajaran tahsin dan tahfizh memberikan dampak positif pada calon pengajar untuk kedepannya dalam hidup beragama saat berada di masyarakat seperti menjadi imam sholat jika suatu saat dibutuhkan..." -Pengajar A-

Menurut hasil wawancara yang dilakukan oleh penulis kepada pengajar baru, ada beberapa hal yang disampaikan oleh para pengajar baru: 

Pengajar B-

“...Para pengajar diharuskan untuk selalu mengkaji ulang materi yang akan disampaikan...” -

"...para pengajar harus lebih bisa mengagendakan jadwal pada saat pembelajaran, melalui online atau pelatihan di majelis..." -Pengajar B-

“.. Prosedur dan mekanisme pembelajaran sejauh ini sudah baik...”-Pengajar B-

"...sebagai pengajar, kami berharap lebih mencintai Alquran, yaitu dengan cara selalu belajar dan mengamalkan isi dari Alquran serta menjalankan ilmunya..." -Pengajar B-

Menurut hasil wawancara yang dilakukan oleh penulis dengan kepada client, ada beberapa hal yang disampaikan oleh para client:

“...mempersiapkan tempat yang nyaman bagi anak, serta perlengakapn belajar seperti: meja, juz amma dan kartu mutabaah untuk menilai, serta waktu yang kualitas seperti jam longgar anak-anak majelis mengaji..." -Client AClient A-

"...evaluasi kualitas pembelajaran, diadakan sesuai jadwal yang telah dibuat oleh pengajar..." -

"...proses kegiatan pembelajaran, dilakukan secara tatap muka langsung dengan cara mendengarkan, menirukan, membaca bersama, kemudian menghafal secara mandiri dipandu oleh pengajar..." -Client B-

“..Prosedur pengajaran sudah disiapkan oleh Pengajar Diponegoro seperti pengajarnya, bahan ajar, metode, serta kartu evaluasi..." -Client B-

Berdasarkan penyajian di atas, terlihat bahwa Evaluasi Kualitas Sistem Pembelajaran di Organisasi Startup Pengajar Diponegoro telah dilakukan secara serius. Tujuan evaluasi kualitas sistem pembelajaran dilakukan untuk meningkatkan kualitas proses pembelajaran disesuaikan dengan perencanaan dan pelaksanaan.

\section{PEMBAHASAN}

\section{Standar Kualitas Sistem Pembelajaran di Organisasi Startup Pengajar Diponegoro}

Untuk mengetahui standar kualitas sistem pembelajaran di Organisasi Startup Pengajar Diponegoro, peneliti menggunakan pedoman sistem penjaminan mutu internal pendidikan akademik, pendidikan vokasi, pendidikan profesi dari Direktorat Penjaminan Mutu tahun 2018. Standar mutu pembelajaran tersebut dilihat dari 4 komponen, yakni: (1) proses atau kegiatan, (2) prosedur atau mekanisme, (3) hasil atau output, dan (4) dampak atau outcomes, yang dilaksanakan oleh Organisasi Startup Pengajar Diponegoro, Yogyakarta berikut hasil analisisnya:

\section{a. Proses atau kegiatan.}

Pada proses kegiatan sistem pembelajaran di Organisasi Startup Pengajar Diponegoro sudah sangat baik sesuai yang disampaikan oleh official pengajar diponegoro yakni: "... dalam perencanaan kualitas sistem pembelajaran, pengajar mengikuti pelatihan online melalui website e-learning. Kualitas pembelajaran pengajar Diponegoro sangat baik, karena semua Official memberikan penjelasan yang sangat mudah dimengerti selama pembelajaran. Pernyataan yang sama sesuai yang disampaikan oleh 
client Organisasi Startup Pengajar Diponegoro tentang proses kegiatan pembelajaran kepada anak didik. Anak didik merasa nyaman dan senang dengan pembelajaran yang disampaikan oleh Pengajar Diponegoro, berikut penyataan client:

"...Perencanaan mutu pembelajaran tahsin dan tahfizh dalam waktu minimal 2 tahun anak diharap sudah bisa membaca Alquran secara tahsin dan tahfizh. Kualitas pembembelajaran baik, anak merasa nyaman den senang dengan metode pembelajarannya..." -Client A-

Proses kegiatan dinyatakan baik, dikarenakan desain yang dirancang waktu awal sudah memenuhi standar, dan data yang ditemukan peneliti yakni: perencanaan kualitas sistem pembelajaran di Organisasi Startup Pengajar dirancang terlebih dahulu sebelum para pengajar melaksanakan pengajaran di Lokasi pembalajaran (privat/majelis).

b. Prosedur atau mekanisme

Pada prosedur atau mekanisme sistem pembelajaran di Organisasi Startup Pengajar Diponegoro sudah sangat baik sesuai yang disampaikan oleh official pengajar diponegoro yakni: terdapat pembagian kelas ketika mengajar. Dalam pengajaran tahsin dan tahfizh, kelas dibagi sesuai umur, karena kita tidak bisa menyamakan pembelajaran murid yang sudah dewasa dengan anak, yang masih anak-anak diselipkan permainan dan cenderung tidak terlalu dipercepat. Sementara orang dewasa kadang mengalami jenuh jika proses pembelajaran dilakukan dengan panjang, ketika waktu sudah habis para murid bisa melakukan konsultasi lewat sosial media/online untuk mendapatkan saran agar pembelajaran dapat dilakukan dengan lebih efektif.

Mekanisme pengajaran yang dilakukan pengajar kepada siswa dengan cara menirukan. Prosedur ini seperti rencana desain pengajaran dimateri pembelajaran online yang ikuti para peserta pengajar ketika pelatihan online. Seorang pengajar yang diwawancarai menyatakan hal yang sama yakni:

"...ketika pengajar mengajar di binaan, pengajar menjelaskan dan memberi contoh dan murid mengikutinya kemudia murid di test satu persatu..." -Pengajar B-

\section{c. Hasil atau output}

Pada prosedur atau mekanisme sistem pembelajaran di Organisasi Startup Pengajar Diponegoro sudah sangat baik sesuai yang disampaikan oleh official dan client Pengajar Diponegoro yakni murid dapat membaca dengan lancar sesuai kaidah ilmu tajwid untuk tahsin dan memiliki hafalan untuk kelas tahfizh. Murid mampu membaca dengan lancar sesuai kaidah ilmu tajwid untuk tahsin dan tahfizh dengan baik. Dari pernyataan hasil dari wawancara tersebut membuktikan bahwa hasil atau output sesuai dengan tujuan awal desain perencanaan pembelajaran yakni: Peserta didik mempunyai kemampuan yang baik dalam belajar membaca Alquran sesuai kaidah ilmu tajwid untuk tahsin dengan baik.

\section{d. Dampak atau outcomes}

Pada dampak atau outcomes sistem pembelajaran di Organisasi Startup Pengajar Diponegoro sudah sangat baik sesuai yang disampaikan oleh official dan pengajar yakni pembelajaran tahsin dan tahfizh memberikan dampak positif pada calon pengajar untuk kedepannya dalam hidup beragama saat berada 
di masyarakat seperti menjadi imam sholat jika suatu saat dibutuhkan. Dan harapan Organisasi Startup Pengajar Diponegoro untuk outcames yang diinginkan kepada semua peserta didik yakni lebih mencintai Alquran selalu belajar dan mengamalkan isinya serta menjalankan ilmunya, pernyataan ini sesuai yang disampaikan pengajar

“...sebagai pengajar, kami berharap lebih mencintai Alquran, yaitu dengan cara selalu belajar dan mengamalkan isi dari Alquran serta menjalankan ilmunya..."- Pengajar B-.

\section{Karakteristik Total Quality Management di Organisasi Startup Pengajar Diponegoro}

Dengan memperhatikan sepuluh karakteristik Total Quality Managemen yang dianggap penting untuk meningkatkan dunia pendidikan, yaitu: (1) fokus pada pelanggan (internal \& eksternal) yakni: official, pengajar, client dan siswa, (2) berorientasi pada kualitas pengajaran, pembelajaran dan hasil ,(3) menggunakan pendekatan ilmiah dengan merancang kegiatan-kegiatan bidang startup sesuai kajian yang matang, sehingga mendapatkan predikat penghargaan di beberapa tempat, (4). memiliki komitmen jangka panjang sesuai grand design Pengajar Diponegoro, (5) kerja sama tim yang solid antara official, pengajar dan client sangat baik, (6) menyempurnakan kualitas secara berkesinambungan dengan cara mengevaluasi setiap pembelajaran di pengajar dan kelas binaan, (7) Mengadakan pendidikan dan pelatihan melalui e-leraning sampai tatap muka, (8) menerapkan kebebasan yang terkendali, dangan dibebaskan melakukan pembelajaran secara mandiri kepada anggotanya. (9) memiliki kesatuan tujuan yakni kemudahaan belajar tahsin dan tahfizh, (10) melibatkan dan memberdayakan untuk membangun ide dan saran Bersama. Dari hasil wawancara yang disampaikan menujukkan bahwa Organisasi Startup Pengajar Diponegoro sudah memenuhi karakteristik Total Quality Managemen.

Berdasarkan temuan khusus, bahwa kualitas sistem Pembelajaran di Organisasi Startup Pengajar Diponegoro dapat disajikan sebagai berikut:

Perencanaan Program untuk meningkatkan kualitas sistem pembelajaran diantaranya:

1. Calon pengajar tahsin dan tahfizh mengumpulkan berkas identitas lengkap ke admin.

2. Ketika pengajar calon pengajar tahsin dan tahfizh di wawancara, calon pengajarnya di tes bacaan Alqurannya terlebih dahulu. Wawancarapun bisa menggunakan Aplikasi Whatsapp, untuk bacaan Alquran bisa direkam.

3. Ketika tahap pengumpulan berkas identitas, wawancara dan tes bacaan Alquran selesai dilakukan, maka peserta melanjutkan pelatihan online dengan moodle e-learning.

4. Selesainya calon pengajar tahsin dan tahfizh belajar online dan me-review semua modul pengajaran, maka calon pengajar berubah statusnya menjadi pengajar tahsin dan tahfizh pengajar diponegoro.

Admin Pengajar Diponegoro memberikan apresiasi, untuk pengajar baru yang telah selesai menjalankan pelatihan online. Apresiasi tersebut dikirim melalui resmi Pengajar Diponegoro ke e-mail pengajar baru. Berdasarkan data dan fakta sebagaimana disajikan pada bagian wawancara di atas, jawaban responden ditunjukkan bahwa perencanaan kualitas sistem pembelajaran di Organisasi Startup Pengajar Diponegoro adalah baik, misalnya Official harus menyiapkan sebuah program website e-learning dan persiapan penyusunan rencana pengajaran dan sudah disiapkan materi-materi terlebih 
dahulu. Ini membuktikan bahwa upaya yang dilakukan bertujuan untuk meningkatkan kualitas system pembelajaran di Pengajar Diponegoro.

Pelaksanaan kualitas sistem pembelajaran diantaranya:

1. Penerapannya pembelajaran sudah baik, karena selain pengajar yang ada sudah mumpuni dalam bidangnya. Rata-rata para pengajarnya juga sudah berpengalaman dan untuk pengajar baru, diberikan bimbingan lewat website untuk mengembangan kemampuannya.

2. Penerapan pembelajaran di kelas binaan sudah sesuai dengan prosedur dari official yakni ketika pengajar mengajar di binaan, pengajar menjelaskan dan memberi contoh dan murid mengikutinya, kemudia murid di test satu persatu.

3. Penerapan pembelajaran tahsin dan tahfizh, siswa nyaman dengan metode yang digunakan oleh pengajar dalam hal pengampaian.

4. Proses pembelajaran tahsin dan tahfizh, dilakukan secara bertahap, berulang-ulang, dan rutin.

Dari data pelaksanaan kualitas sistem pembelajaran di atas, terlihat bahwa Organisasi Startup Pengajar Diponegoro memiliki kepedulian besar dalam memperbaiki kualitas sistem pembelajaran di seluruh kegiatan proses pembelajaran telah dilakukan diatur dalam perencanaan, sehingga semua ini menjadi wajib dilakukan dengan baik oleh para official, para pengajar, dan client menggunakan pelayanan pengajar tahsin dan tahfizh. Semuanya telah terjadi dibuat dengan baik oleh Organisasi Startup Pengajar Diponegoro dan tim official dari pengembangan sekolah melalui proses perencanaan.

Evaluasi kualitas sistem pembelajaran diantaranya:

1. Evaluasi dilakukan secara langsung lewat pengajar yang bersangkutan maupun menggunakan kertas penilaian untuk melihat perkembangan dari calon pengajar baru yang dilatih dari waktu ke waktu

2. Tes calon pengajar baru dilakukan pada waktu yang telah ditentukan dengan cara melakukan tes bacaan maupun hafalan lewat sosial media atau tatap muka

Evaluasi penggunaan sumber daya media perlu adanya evaluasi (Rodrigues, Isotani, \& Zárate, 2018). Berdasarkan penyajian di atas, terlihat bahwa Evaluasi Kualitas Sistem Pembelajaran di Organisasi Startup Pengajar Diponegoro telah dilakukan secara serius. Tujuan Evaluasi Kualitas Sistem Pembelajaran dilakukan untuk meningkatkan kualitas proses pembelajaran disesuaikan dengan perencanaan dan pelaksanaan.

\section{KESIMPULAN DAN SARAN}

Berdasarkan ilustrasi di atas tentang kualitas sistem pembelajaran di Organisasi Startup Pengajar Diponegoro, mampu ditarik kesimpulan sebagai berikut:

1. Perencanaan Kualitas Sistem Pembelajaran di Organisasi Startup Pengajar Diponegoro. Admin Pengajar Diponegoro memberikan apresiasi, untuk pengajar baru yang telah selesai menjalankan pelatihan online. Apresiasi tersebut dikirim melalui resmi Pengajar Diponegoro ke e-mail pengajar baru. Berdasarkan data dan fakta sebagaimana disajikan pada bagian wawancara di atas, jawaban responden ditunjukkan bahwa perencanaan kualitas sistem pembelajaran di Organisasi Startup Pengajar Diponegoro adalah baik, misalnya: rencana Official harus menyiapkan sebuah program website e-learning dan Rencana Pelaksanaan Pembelajaran (RPP) pengajaran sudah disiapkan 
materi-materi terlebih dahulu. Ini membuktikan, bahwa upaya yang dilakukan bertujuan untuk meningkatkan kualitas sistem pembelajaran di Pengajar Diponegoro.

2. Pelaksanaan kualitas sistem pembelajaran, dan penerapannya sudah baik, terlihat bahwa Organisasi Startup Pengajar Diponegoro memiliki kepedulian besar dalam memperbaiki kualitas sistem pembelajaran. Penerapan di seluruh kegiatan proses pembelajaran telah dilakukan, dan diatur dalam perencanaan, sehingga semua kegiatan menjadi wajib, untuk dilakukan dengan baik oleh para official, para pengajar, dan client yang menggunakan pelayanan pengajar tahsin dan tahfizh. Semuanya telah dibuat dengan baik oleh Organisasi Startup Pengajar Diponegoro dan tim official dari pengembangan pembelajaran, melalui proses perencanaan.

3. Evaluasi kualitas sistem pembelajaran mendapat kategori baik, terlihat bahwa evaluasi kualitas sistem pembelajaran di Organisasi Startup Pengajar Diponegoro telah dilakukan secara serius. Tujuan evaluasi kualitas sistem pembelajaran dilakukan untuk meningkatkan kualitas proses pembelajaran disesuaikan dengan perencanaan dan pelaksanaan.

4. Standar kualitas sistem pembelajaran di Organisasi Startup Pengajar Diponegoro, mendapatkan hasil, di antaranya: (1) proses atau kegiatan kualitas pembelajaran pengajar Diponegoro sangat baik, karena semua Official memberikan penjelasan yang sangat mudah dimengerti selama pembelajaran, dan kualitas pembembelajaran yang baik membuat anak merasa nyaman den senang dengan metode pembelajarannya, (2) prosedur atau mekanisme pengajaran tahsin dan tahfizh, kelas dibagi sesuai umur, dan pengajaran tahsin dan tahfizh yang dilakukan oleh pengajar kepada siswa, dengan cara menirukan, (3) hasil atau output tahsin dan tahfizh yaitu peserta didik mempunyai kemampuan yang baik dalam belajar membaca Alquran sesuai kaidah ilmu tajwid untuk tahsin dengan baik, dan (4) dampak atau outcomes. Pembelajaran tahsin dan tahfizh yaitu calon pengajar untuk kedepannya dalam hidup beragama saat berada di masyarakat seperti menjadi imam sholat jika suatu saat dibutuhkan, dan lebih mencintai Alquran selalu belajar dan mengamalkan isinya serta menjalankan ilmunya. Keseluruhan standar kualitas sistem pembelajaran di Organisasi Startup Pengajar Diponegoro, mendapatkan hasil baik.

5. Dengan memperhatikan sepuluh karakteristik Total Quality Managemen disampaikan menujukkan bahwa Organisasi Startup Pengajar Diponegoro sudah memenuhi karakteristik Total Quality Managemen.

Berdasarkan dari kesimpulan penelitian ini, peneliti memberikan saran untuk perancang desain elearning memperhatikan perencanaan, pelaksanaan, evaluasi, standar kualitas dan karakteristik Total Quality Management supaya kualitas sistem pembelajaran lebih maksimal.

\section{DAFTAR PUSTAKA}

Depag. (1993). Al-Qur'an Terjemahan. Jakarta: Intermasa

Al-Rahmi, W. M., Alias, N., Othman, M. S., Marin, V. I., \& Tur, G. (2018). A model of factors affecting learning performance through the use of social media in Malaysian higher education. Computers \& Education, 121, 59-72. doi:10.1016/j.compedu.2018.02.010. Diambil pada tanggal 1 juli 2019, dari https://www.sciencedirect.com/science/article/pii/S0360131518300435

Banerjee, S., Arora, S., John, G., Dutta, S., Kalra, R., \& Sapracet, R. (2019). Effectiveness of selfinstructional module on knowledge, attitude and practice regarding pharmacovigilance among staff nurses. Current Medicine Research and Practice, 9(3), 93-97 doi:10.1016/j.cmrp.2019.05.001. Diambil pada tanggal 2 juli 2019 dari https://www.sciencedirect.com/science/article/pii/S2352013215000666 
Dhaliwal, N., Simpson, F., \& Kim-Sing, A. (2018). Self-paced online learning modules for pharmacy practice educators: development and preliminary evaluation. Currents in Pharmacy Teaching and Learning, 10(7), 967-974. doi:10.1016/j.cptl.2018.04.017. Diambil pada tanggal 19 mei 2019, dari https://www.sciencedirect.com/science/article/abs/pii/S1877129717303003

Dimyati \& Mudjiono. (2002). Belajar dan Pembelajaran. Jakarta: Rineka Cipta.

Direktorat Penjaminan Mutu. (2018). Pedoman Sistem Penjaminan Mutu Internal Pendidikan Akademik, Pendidikan Vokasi, Pendidikan Profesi, Pendidikan Jarak Jauh. diambil pada Tanggal 18 September 2019 dari https://spmi.ristekdikti.go.id/uploads/publications /Buku\%20Pedoman\%20SPMI\%202018.pdf

Hamalik, O. (2006). Proses Belajar Mengajar. Jakarta: PT. Bumi Aksara.

Imana, Y. (2016). Panduan Fun Tahsin Tilawah Terpadu. Bandung: LP2TQ Baitul Quran.

Lestari, E. Sunardi, Suryani, N. (2017). Pengaruh penggunaan media berbasis information technology pada pembelajaran IPA terhadap prestasi belajar ditinjau dari kemandirian belajar. Teknodika, 15(1), 16-25. Diambil pada tanggal 22 oktober 2019 dari: https://jurnal.uns.ac.id/Teknodika/article/view/34925/22856.

Molenaar, I., Horvers, A., \& Baker, R. S. (2019). What can moment-by-moment learning curves tell about students' self-regulated learning? Learning and Instruction, 5(3) 1-35. doi:10.1016/j.learninstruc.2019.05.003. Diambil pada tanggal 1 juli 2019, dari https://www.sciencedirect.com/science/ article/pii/S0959475218304870

Pirmansah, A., Suharno, Fadhilah, S. S. (2017). Analisa dan Perancangan E-Learning Pembelajaran Pemrograman Dasar Kelas X SMK. Teknodika, 15(2),12-24. Diambil pada tanggal 22 oktober 2019 dari: https://jurnal.uns.ac.id/Teknodika/article/view/34743/22749.

PLPG. (2016). Bahan Ajar PLPG Materi Keprofesionalan dan Pedagogik. UNNES. Dirjen GTK: UMP.

Rauf, A.A.A. (2004). Kiat Sukses Menjadi Hafidz Qur'an Da'iyah. Bandung: PT. Syaamil Cipta Media.

Rochaety, E., Rahayuningsih, P., \& Yanti, P. G. (2005). Sistem Informamsi Manajemen Pendidikan. Jakarta: Bumi Aksara

Rodrigues, M. W., Isotani, S., \& Zárate, L. E. (2018). Educational data mining: a review of evaluation process in the e-learning. Telematics and informatics, 35(6), 1701-1717. doi:10.1016/j.tele.2018.04.015. Diambil pada tanggal 19 mei 2019, dari https://www.sciencedirect.com/science/article/abs/pii/S073658531 7306639

Sagala, S. (2004). Manajemen Berbasis Sekolah \& Masyarakat. Bandaung: alfabeta

Saifulloh, M., Muhibbin, Z., \& Hermanto. (2012). Strategi peningkatan mutu pendidikan di sekolah. Jurnal Sosial Humaniora, 5(2), 206-207.

Salahudin, A. (2017). Pendidikan Karakter, Pendidikan berbasis Agama dan Budaya Bangsa. Bandung: Pustaka Setia 
Sallis, E. (2006). Total Quality Management In Education (alih Bahasa Ahmad Ali Riyadi). Jogjakarta: IRCiSoD

Seftiawan, D. (2018). 630.000 Orang Sarjana Masih Menganggur. diambil pada tanggal 18 September 2019 dari https://usd.ac.id/lembaga//pmai/wp-content/uploads/2019/06/Manul-Mutu-ProsesPembelajaran.pdf

Subroto, S. (1997). Proses Belajar di Sekolah. Jakarta: Rineka Cipta.

Ira. (2017). Marak Sarjana Menganggur, Peningkatan Mutu Pendidikan Tinggi Butuh Relevansi. diambil $\begin{array}{lllll}\text { pada tanggal } & 18 & \text { september } & 2019\end{array}$ http://sumberdaya.ristekdikti.go.id/index.php/2017/07/18/marak-sarjana-menganggurpeningkatan-mutu-pendidikan-tinggi-butuh-relevansi/

Tiari, D. A., Suryani, N., \& Suharno. (2016). Penerapan multimedia interaktif untuk meningkatkan motivasi dan hasil belajar IPA materi struktur organ tubuh manusia dan fungsinya. Teknodika, 14(1), 22-30. Diambil pada tanggal 22 oktober 2019 dari: https://jurnal.uns.ac.id/Teknodika/article/view/34696/22715

Warsito, B. (2008). Teknologi Pembelajaran Landasan dan Aplikasinya. Jakarta: Rineka Cipta

Yunus, M. (1989). Kamus Arab Indonesia. Jakarta: Hindakarya Agung 